\title{
Mathematical Modelling and Software Development to Optimize the Composition of Four-Component Nanofilled Systems
}

\author{
V. G. Rezanova and N. M. Rezanova \\ Kyiv National University of Technology and Design, \\ 2, Nemirovich-Danchenko Str., \\ UA-01011 Kyiv, Ukraine
}

With the application of the simplex-centroid method, a plan of experiments in the studied area of factor space for the four-component heterogeneous systems is developed. The required number of points in a plan is 14 . The placement of points-candidates in a simplex is performed by means of the McLeanAnderson algorithm. To calculate the coordinates of the experiment-plan points, a program is developed in Delphi environment. The results of the experiments created a mathematical model in the form of a set of regression equations, which establishes the relationship between the content of ingredients and the properties of the four-component composition. The optimization of the composition of polypropylene/copolyamide (PP/CPA) mixture, which contains silica as a nanofiller and silicone substance as a compatibilizer, is performed using the generalized Harrington criterion. As found, the combined action of both modifying additives with a total content of $2.0 \mathrm{wt} . \%$ allows to realize the process of formation of the PP microfibrils within the CPA matrix and to increase the concentration of dispersed-phase component to almost 45 wt.\%. Complex polypropylene filaments obtained from composition with optimized percentage are characterized by high strength, self-abrasion resistance, and hygroscopicity.

За допомогою симплекс-центроїдної методи розроблено план проведення експериментів у досліджуваній області факторного простору для чотирокомпонентних гетерогенних систем. Необхідна кількість точок плану в ній складає 14. Розміщення точок-кандидатів у симплексі проведено за алгоритмом Макліна-Андерсона. Для розрахунку координат точок плану експерименту розроблено програму у середовищі Delphi. За результатами експериментів створено математичний модель у вигляді системи регресійних рівнянь, що встановлює взаємозв'язок між вмістом інгредієнтів і властивостями чотирокомпонентної композиції. Оптимізацію складу суміші поліпропілен/співполіамід (ПП/СПА), яка містила як нанонаповнювач кремнезем, а як компатибілізатор - кремнійорганічну речовину, виконано з використанням узагальненого Харингтонового критерію бажанос- 
ти. Встановлено, що сумісна дія обох модифікувальних добавок загальним вмістом у 2,0 мас.\% уможливлює реалізувати процес формування мікрофібрил ПП в матриці СПА та досягти збільшення концентрації компонента дисперсної фази майже до 45 мас.\% . Комплексні поліпропіленові нитки, одержані з композиції із оптимізованим складом, характеризуються підвищеними міцністю, стійкістю до самостирання та гігроскопічністю.

Key words: simplex-centroid design, plan of experiment, software, mathematical model, four-component system.

Ключові слова: симплекс-центроїдний план, план експерименту, програмне забезпечення, математична модель, чотирокомпонентна система.

(Received 28 February, 2020; in revised form, 23 September, 2020)

\section{INTRODUCTION}

The leading global trend in the production of synthetic fibrous materials is the development of methods of modifying properties in the direction of reducing the diameters of individual filaments to micro- and nanosize and introducing into their structure of substances in nanostructure. Fibres with micron sizes are obtained by aerodynamic formation, and with nanosizes, by electroforming. Today, one of the most effective ways to obtain ultrathin fibres is to process melts of thermodynamically incompatible polymer mixtures. The formation in situ micro- or nanofibrils of one component in the matrix of another has been implemented for many pairs of polymers by extrusion methods [1-7], blow-out [8,9], uniaxial stretching [10-12], and $3 D$-forming (fused deposition modelling) [13]. In this case, diameter of the microfibrils is largely determined by the rheological characteristics of the components of mixture and the degree of their compatibility at the interphase. Improvement of microfibrillary morphology (reduction of diameters of fibrils and increase of their mass fraction) is achieved by introduction of special substances into the mixture, namely, compatibilizers $[14,15]$, nanoadditives $[5-7,11]$ or their compositions $[11,16$, 17].

The modifying effect of the additives on the structure of the threeand four-component compositions is manifested in the decrease of value of interfacial tension and the increase of stability of liquid cylinders (fibrils). In modified systems, the degree of dispersion of the fibreforming polymer and the kinetic stability of the melts increase, and drops aggregation processes are inhibited. Thus, the use of silicone fluid as compatibilizers allows to increase the content of the dispersed phase component in the polypropylene/copolyamide (PP/CPA) mixture and to realize the microfibrillar structure for the ratios of components related to the phase change region [14, 15]. Thus, obtained PP 
microfibrils with average diameters comparable with that were obtained from mixture of the composition 20/80 wt.\%. Nanofillers in the melt mixture of thermodynamically incompatible components play a dual role. First, they act as compatibilizers contributing to the improvement of morphology. Secondly, they give the fibrous materials unique properties inherent in the substances in the nanostructure. By introducing into the melt a mixture of PP/CPA of carbon nanotubes [7], silica nanoparticles [5, 6], or composite additives based on it [18, 19] have obtained complex threads of nanofilled PP microfibrils with a high specific surface area and improved mechanical properties indicators. The hygroscopicity of modified filaments increases 15-20 times, compared to textile polypropylene threads obtained by traditional technology. The use of silver-containing additives $\left(\mathrm{Ag} / \mathrm{SiO}_{2}\right.$ and $\mathrm{Ag} / \mathrm{Al}_{2} \mathrm{O}_{3}$ ) made it possible to provide bactericidal properties to fibres and filter materials $[19,20]$. It should be emphasized that filters obtained from the processing of nanofilled systems combine high cleaning efficiency with increased productivity [20]. The simultaneous use of compatibilizer and nanoadditive is more effective than of individual substances due to their synergistic action $[11,16,17]$. Thus, the introduction of nanoparticles $\mathrm{Ag} / \mathrm{SiO}_{2}$ and sodium oleate (compatibilizer) into the melt mixture PP/CPA led to decrease of the average diameter of microfibrils from $3.5 \mu \mathrm{m}$ (for the original mixture) to $1.1 \mu \mathrm{m}$ (for four-component) [16]. Polyethylene terephthalate (PET) fibrils in the PP matrix with the maximum length and minimum diameter were obtained by modifying the PET/PP mixture with simultaneous introduction of grafted maleic anhydride and $\mathrm{TiO}_{2}$ nanoparticles into it [11].

The technology of obtaining ultrathin fibres by processing of polymer mixture melt involves two main stages: the formation of composite products (films, monofilaments) with a given structure (isotropic matrix, filled with micro- or nanofibrils of the other component) and the extraction of matrix polymer with an inert solvent [5]. When selecting the composition of mixture to obtain thin-fibre materials, it is important to combine their desired properties with the maximum content of the component of the dispersed phase. This is due to the fact that increasing the concentration of fibre-forming polymer is a prerequisite for improving the economic performance of production and reducing the ecological burden on the environment.

In order to determine the relationship between the content of ingredients in the investigated four-component compositions and their properties, a considerable number of multifactorial experiments should be performed (even without parallel experiments). Studies of polymer systems are associated with significant time and material costs, as the impact of each factor is evaluated separately. Occasional$l y$, the number of experiments is artificially decreased by reducing the amount of factor-space under study or the number of levels of parame- 
ter variation. In both cases, the degree of reliability of the conclusions that are made according to the results of the experiments decreases. One of the ways to accelerate scientific research and find solutions that are as close to optimal as possible with minimal cost is to use mathematical methods of experiment planning and analysis [21].

The goal of the work is to investigate and automate the process of experiment planning in order to optimize the composition of a nanofilled polypropylene/copolyamide mixture with the maximum possible content of PP to obtain complex microfibrillar filaments with predicted characteristics.

\section{MATERIALS AND METHODS}

For planning of experiments, we chose the simplex-grid method, which is used to study multicomponent systems [21].

The ratio of ingredients in the compositions must sati ${ }_{\mathrm{s}}$ fy the following condition:

$$
\sum_{i=1}^{q} x_{i}=1
$$

where $x_{i}$ is relative concentration of ingredients $\left(x_{i} \geq 0\right)$; $q$ is a number of ingredients $(q \geq 2)$. This condition defines the range of allowable variables, the so-called simplexes. For a four-component system, it looks like a tetrahedron. In this case, its faces correspond to the simplexes of three-component mixtures, and the points in the middle correspond to the four-component mixture. In simplex-grid plans for the construction of models of degree $n$, the experimental points are arranged symmetrically in the simplex, using for each component $x_{i}$ $(i=1, q)$ of $(q+1)$ equally-spaced levels ranging from 0 to $1: x_{i}=0,1 / n$, $2 / n, \ldots, n / n=1$. All possible combinations of these levels are plans or simplex grids that are completely saturated (the number of experiments in them is equal to the number of unknown coefficients of the corresponding model). The experimental points are located mainly on the periphery of the simplex. Simplex-centroid plans were used to take into account of the results of experiments in the middle of the simplex [22]. They contain points with coordinates: $(1 ; 0 ; \ldots ; 0)$; $(1 / 2 ; 1 / 2 ; 0 ; \ldots ; 0) ; \ldots ;(1 / q ; 1 / q ; . . ; 1 / q)$, as well as any points, which can be obtained by rearranging these coordinates. The experimental points are located at the vertices of the simplex, the middle of the sides, the centres of faces of different dimensions, one point in the centre of the simplex. In this case, from $2^{q-1}$ experimental data, $q$ points have one non-zero component, $C_{q}^{2}, C_{q}^{3}, C_{q}^{4}$ points have two, three and four non-zero components, respectively, and one point contains all components. 
To automate the process of creating plan of experiment, software was developed in Delphi environment in Object Pascal [23-25].

Experimental studies were performed using a thermodynamically incompatible polypropylene (PP)/copolyamide (CPA) mixture, in which the A7 isotactic polypropylene was dispersed phase, and the alcoholsoluble copolyamide of brand PA-6/66 (caprolactam and hexamethylenedinipinate 50:50 copolymer) was the dispersion medium. As nanofiller, pyrogenic silica $\left(\mathrm{SiO}_{2}\right)$ of brand A-300 with a specific surface area of $324 \mathrm{~m}^{2} / \mathrm{g}$ was selected, and as a compatibilizer, silicone substance (polyethylsiloxane) of brand PES- 5 was selected. Mixing of components was carried out on a worm-disk extruder. Modifying additives were preintroduced into the PP melt, and the obtained granules were mixed with a matrix polymer (CPA). The processes of structure formation of PP in the matrix were investigated using an optical microscope brand MBR15; then, the average diameter of the microfibrils in the beam after extraction of CPA from the composite extrudate was determined. Complex monothreads were formed from the tested mixtures on a laboratory stand through a $780 \mu \mathrm{m}$-diameter die at $190^{\circ} \mathrm{C}$, with drawing degree of $1000 \%$. Thermoorientation elongation was carried out at a temperature of $150^{\circ} \mathrm{C}$ with a multiplicity of 5 . Complex threads of nanofilled PP microfibers were obtained by extracting a matrix polymer from composite threads with $70 \%$ aqueous ethyl alcohol at $70 \pm 5^{\circ} \mathrm{C}$ in a Soxhlet apparatus. The strength of complex filaments at break $(\mathrm{P})$ was determined using a breaking machine of the KT $7010 \mathrm{AZ}$ brand. The hygroscopicity of the filaments was evaluated by the weight method with an air humidity of $98 \%$.

To build the experiment plan, two-way restrictions, $0 \leq a_{i} \leq x_{i} \leq b_{i} \leq 1, i=\overline{1, q}$, were imposed on the contents of the individual ingredients of the four-component system, where $a_{i}, b_{i}$ are the upper and lower bounds of the constraints of each of the components should not be equal to each other. The input variables were $x_{1}, x_{2}, x_{3}$, $x_{4}$, i.e., relative concentrations of $\mathrm{PP}, \mathrm{CPA}$, nanosize $\mathrm{SiO}_{2}$ and organosilicon fluid, respectively. The concentration of the ingredients of the test composition is subject to the following restrictions:

$$
0.2 \leq x_{1} \leq 0.45 ; 0.55 \leq x_{2} \leq 0.80 ; 0.001 \leq x_{3} \leq 0.010 ; 0.005 \leq x_{4} \leq 0.040 \text {. }
$$

The condition (1) must be fulfilled. Output parameters: $y_{1}$ is average diameter of PP microfibers; $y_{2}$ is strength of complex filaments at break; $y_{3}$ is the hygroscopicity of the filaments.

\section{RESULTS AND DISCUSSION}

When planning an experiment, the choice of a mathematical function, 
which describes the object under study, is made, namely, its adequacy and simplicity. The response function links the initial parameters to the factors that change during the experiments: $y=\varphi\left(x_{1}, x_{2}, x_{3}, x_{4}\right)$. Response surfaces for multifactor systems are complex. To describe them, polynomials of high degrees are required and, as a result, a large number of experiments, since a polynomial of degree $n$ of $q$ variables has $C_{q+n}^{n}$ coefficients. To develop a model that interconnects the content of the components of the compatibilized nanofilled PP/CPA mixture and the properties of the microfibrillar filaments, a third-order incomplete polynomial was used, as it well describes the behaviour of four-component systems [21, 22]:

$$
\begin{aligned}
& \hat{y}=\beta_{1} x_{1}+\beta_{2} x_{2}+\beta_{3} x_{3}+\beta_{4} x_{4}+\beta_{12} x_{1} x_{2}+\beta_{13} x_{1} x_{3}+\beta_{14} x_{1} x_{4}+\beta_{23} x_{2} x_{3}+ \\
& +\beta_{23} x_{2} x_{3}+\beta_{23} x_{2} x_{3}+\beta_{123} x_{1} x_{2} x_{3}+\beta_{124} x_{1} x_{2} x_{4}+\beta_{134} x_{1} x_{3} x_{4}+\beta_{234} x_{2} x_{3} x_{4},
\end{aligned}
$$

where $\beta_{i}, \beta_{i j}, \beta_{i j k}$ are coefficients of the polynomial, and $i \neq j \neq k ; i, j$, $k=1,2,3,4$.

To estimate the numerical values of the coefficients of Eq. (3), it is necessary to draw up a plan for conducting experiments in the studied area of factor space.

When designing an experiment plan that meets some criterion of optimality, the coordinates of the candidate points were determined, namely: vertices of the polygon, midpoints of edges, centres of faces, general centroid. To this aim, we used the McLean-Anderson method [22], according to which all possible combinations of lower and upper levels and for each component were selected, omitting the contents of one of them. For the studied four-component mixture, one of the options may be $a_{1} ; b_{2} ;-; b_{4}$, with the total number of combinations (at $q=4$ ) equal to 32 . Subsequently, from combinations obtained where selected those, for which the concentration is less than one, and added the contents of the missing component. Variants with added components that satisfy conditions (1) and (2) represent the vertices of the desired polyhedron. The resulting figure contains the edges of the first and second orders: the first order is the edges that have two identical coordinates and the second one has one coincident coordinate. The recurring vertices were excluded.

The next step was the selection of $r$-dimensional faces, or hyperfaces of polyhedron, and $1 \leq r \leq q-2$. At $r=1$, we have an edge; at $r=2$, this is a face, and at $r=3$, this is a hyperface. A face with dimension $r$ is formed by a group of vertices that have the same coordinates in number of $q-r-1$. For a four-component system, a three-dimensional polyhedron is formed. Its edges have vertices with two identical coordinates, and its faces are with one identical coordinate. The maximum number of vertices having $q-r-1$ same coordinates was chosen because they form the $r$-dimensional face. The total number of $r$ - 
dimensional faces was calculated by the formula:

$$
\sum_{q-r-1=1}^{q-2} C_{q}^{q-r-1} 2^{q-r-1}
$$

In each of the selected faces, the coordinates of the centres (centroids) were determined as the average of the coordinates of the vertices forming the corresponding face. The coordinates of the common centre of the polyhedron were then calculated as the average of the coordinates of all vertices. As a result, 27 points-candidates for the experiment plan were obtained. To determine the numerical values of the coefficients of polynomial (3), it is sufficient to have 14 points of plan [21]. In order to select specific points for experiments, a method of drawing a plan containing a given number of experiments was used. It lies in the fact, that these points must be as far apart as possible from each other in the factor space defined by constraints on the simplex. To do this, the distance between all candidate points and the centre of the polyhedron $\left(d_{m n}\right)$ was calculated using the formula:

$$
d_{m n}=\left[\sum_{1 \leq i \leq q}\left(\frac{x_{m i}-x_{n i}}{b_{i}-a_{i}}\right)^{2}\right]^{1 / 2},
$$

where $m$ and $n$ are numbers of two points; $i$ is a number of the component.

Two points that are at the largest distance from the centre were included in the plan. Between each point obtained and the remaining points, the distances were calculated by the formula (5). Then, we chose the normalized distance $\left(d_{m n}^{\prime}\right)$, using the condition:

$$
d_{u}^{c p} \leq d_{m n}^{\prime} \leq\left(2 d_{u}^{c p}\right)^{1 / 2},
$$

where $d_{u}^{c p}$ is the average distance of the point from the centre.

Points that have distances to two already selected points of the plan, which are greater than the normalized distance, are included in the plan and the rest are eliminated.

In order to automate the process of experimental studies to optimize the composition of a nanofilled compatibilized PP/CPA mixture, software was developed in Delphi [23-25]. In the created program, the researcher must only input the content of each of the components of the mixture (arrays $a$ and $b$ ). The program then performs the following steps, according to the algorithm described above:

- determines coordinates of the vertices of polyhedron;

- selects $r$-dimensional faces of the polyhedron $(1 \leq r \leq q-2)$ and determines coordinates of their centroids;

- calculates coordinates of the common centre of polyhedron; 
- finds distances from the candidate points into the plan to the common centre and identifies two points that are in the largest distance from the centre;

- eliminates points for which the distance to the two selected is less than normalized;

- determines coordinates of the points included into the plan.

Thus, in a few seconds, the program draws up plan of experiment for studying of the composition $\mathrm{PP} / \mathrm{CPA} /$ nanoadditive/compatibilizer according to the McLean-Anderson algorithm, which contains 14 necessary points (Fig.).

Experimental studies, carried out in accordance with the drawn up plan, showed that microfibrillar structure is realized for all compositions. The ratio of organosilicon fluid and silica significantly affect the formation of the morphology of the mixture PP/CPA (the average diameter of microfibrils varies from 1.6 to $7.1 \mu \mathrm{m}$ ). All modified systems are stably processed into composite monothreads. After extraction of the matrix polymer from them, complex polypropylene microfibrillar filaments were obtained, the properties of which are given in Table.

Based on the table data, the coefficients of the polynomial (3) are calculated using the least squares method in matrix form. The calculations were made using a previously created program in the Delphi environment in Object Pascal [27]. The result is a system of equations (7), which is a mathematical model that describes the process under study:

$$
\left\{\begin{array}{c}
\hat{y}=3,46 x_{1}+5,24 x_{2}+4,17 x_{3}-5,33 x_{4}+2,78 x_{1} x_{2}+6,37 x_{1} x_{3}- \\
-46,83 x_{1} x_{4}+7,89 x_{2} x_{3}-24,61 x_{2} x_{4}-49,05 x_{3} x_{4}-161,35 x_{1} x_{2} x_{3}- \\
-0,97 x_{1} x_{2} x_{4}+4,94 x_{1} x_{3} x_{4}+3995 x_{2} x_{3} x_{4} ; \\
\hat{y}=359,9 x_{1}+340,4 x_{2}+408,8 x_{3}-263,9 \beta_{4} x_{4}+457,7 x_{1} x_{2}+ \\
+548.6 x_{1} x_{3}-2878 x_{1} x_{4}-1128 \beta_{23} x_{2} x_{3}-1034 \beta_{23} x_{2} x_{4}-2311 x_{3} x_{4}- \\
-5155 x_{1} x_{2} x_{3}-446,1 x_{1} x_{2} x_{4}+248,4 x_{1} x_{3} x_{4}-71890 x_{2} x_{3} x_{4} ; \\
\hat{y}=0,85 x_{1}+0,79 x_{2}+1,01 x_{3}-3,69 x_{4}+0,86 x_{1} x_{2}+1,58 x_{1} x_{3}- \\
-19,72 x_{1} x_{4}-8,00 x_{2} x_{3}-9,78 x_{2} x_{3}-16,87 x_{2} x_{3}-40,47 x_{1} x_{2} x_{3}- \\
-9,79 x_{1} x_{2} x_{4}+1,34 x_{1} x_{3} x_{4}-116,3 x_{2} x_{3} x_{4} .
\end{array}\right.
$$

After determining coefficients of the regression equation, the statistical analysis of the obtained results is performed; equations are tested for adequacy, that is, the ability of the model to predict the results of studies in some area with the required accuracy [26, 27]. For this purpose, additional experiments were carried out at the so-called checkpoints; the values of the Fisher criterion were calculated for all output variables and compared with tabular data. The obtained values of the specified criterion testify to the adequacy of the developed mod- 


\begin{tabular}{|c|c|c|c|c|c|c|}
\hline \multirow{3}{*}{$\begin{array}{l}\text { Number of } \\
\text { experimen } \\
\text { point }\end{array}$} & \multicolumn{6}{|c|}{ Coordinates of plan points } \\
\hline & & $X 1$ & $X 2$ & $\times 3$ & $X 4$ & \\
\hline & 1 & 0,2 & 0,794 & 0,005 & 0,001 & \\
\hline & 2 & 0,444 & 0,55 & 0,005 & 0,001 & \\
\hline & 3 & 0,2 & 0,759 & 0,04 & 0,001 & \\
\hline & 4 & 0,409 & 0,55 & 0,04 & 0,001 & \\
\hline & 5 & 0,2 & 0,75 & 0,04 & 0,01 & \\
\hline & 6 & 0,4 & 0,55 & 0,04 & 0,01 & \\
\hline & 7 & 0,2 & 0,7675 & 0,0225 & 0,01 & \\
\hline & 8 & 0,4175 & 0,55 & 0,0225 & 0,01 & \\
\hline & 9 & 0,2 & 0,7545 & 0,04 & 0,0055 & \\
\hline & 10 & 0,4045 & 0,55 & 0,04 & 0,0055 & \\
\hline & 11 & 0,3 & 0,65 & 0,04 & 0,01 & \\
\hline & 12 & 0,3045 & 0,6545 & 0,04 & 0,001 & \\
\hline & 13 & 0,3175 & 0,6675 & 0,005 & 0,01 & \\
\hline & 14 & 0,30225 & 0,65225 & 0,04 & 0,0055 & \\
\hline
\end{tabular}

Fig. Program obtained plan of experiment for studying of the composition $\mathrm{PP} / \mathrm{CPA} /$ nanoadditive/compatibilizer.

el.

The system of regression equations (7) was used for multicriteria search of the optimal composition of the test mixture using the generalized criterion of desirability $D$ (Harrington criterion) [22]. Possible values of $D$ are within the interval $[0,1](0$ corresponds to the totally inappropriate value of the given response; 1 corresponds to its best value). To determine criterion $D$, the set response values were converted to a dimensionless scale of desirability for each output parameter. The calculated value of the Harrington test was 0.9276 . The optimum composition of $\mathrm{PP} / \mathrm{CPA} /$ nanoadditive/compatibilizer mixture was determined using previously developed software [27]. With the specified value of the criterion of desirability, the ratio of the components of mixture for forming monofilaments was as follows [wt.\%]: polypropylene -43.6 ; copolyamide -54.4 ; nanosize silica -1.9 ; organosilicon fluid - 0.1. Investigation of the properties of complex microfibrillar filaments formed from the mixture of the optimal composition, showed their significant improvement.

Therefore, the tensile strength is at the level of the best samples of traditional textile PP threads (410 MPa). The use of silicone fluid provides a significant increase in the resistance of the tested threads to selfabrasion (1027 against 516 thousand cycles for textile threads). Obviously, this may be due to the fact that the silicone liquids are not compatible with most organic substances and are displaced to the surface 
TABLE. Influence of the composition of the mixture on the average diameter of PP microfibrils and on the properties of complex filaments.

\begin{tabular}{cccc}
\hline $\begin{array}{c}\text { Plan point } \\
\text { number }\end{array}$ & $\begin{array}{c}\text { The average diameter of } \\
\text { microfibrils, } \mu \mathrm{m}\end{array}$ & $\begin{array}{c}\text { Strength of } \\
\text { the filaments, MPa }\end{array}$ & $\begin{array}{c}\text { Hygroscopicity of } \\
\text { the filaments, \% }\end{array}$ \\
\hline 1 & 1.6 & 250 & 0.51 \\
2 & 4.4 & 280 & 0.43 \\
3 & 3.3 & 345 & 0.69 \\
4 & 7.1 & 410 & 0.63 \\
5 & 3.4 & 365 & 0.37 \\
6 & 6.2 & 325 & 0.31 \\
7 & 3.5 & 380 & 0.40 \\
8 & 5.4 & 355 & 0.29 \\
9 & 2.7 & 420 & 0.53 \\
10 & 6.5 & 400 & 0.48 \\
11 & 4.2 & 410 & 0.34 \\
12 & 3.7 & 445 & 0.68 \\
13 & 4.4 & 390 & 0.59 \\
14 & 3.2 & 470 & 0.73 \\
\hline
\end{tabular}

when injected in small amount. In the melt of the PP/CPA mixture, polyethylsiloxane migrates to the interphase area, and after extraction of the matrix polymer remains on the microfibril surface and reduces the friction coefficient of the filaments. It should be noted that the modified complex filaments are also characterized by improved hygienic properties: their hygroscopicity is $\mathbf{1 7}$ times higher than that of ordinary textile filaments.

\section{CONCLUSIONS}

Using a simplex-centroid algorithm, a technique was developed to plan experimental studies on the effect of the ratio of ingredients in a fourcomponent heterogeneous polymer system on its morphology and products properties. Points-candidates for experiment plan were placed in a simplex by the McLean-Anderson method. To calculate the coordinates of the points of the experiment plan, the contents of which are subject to two-way restrictions, a program was developed in Delphi.

According to the results of the experiments conducted according to the plan, a mathematical model of the process under study in the form of a system of regression equations was developed. The model was used for multicriteria searching for the optimal composition of nanofilledcompatibilized mixtures using the generalized Harrington criterion. It 
is established that the simultaneous introduction into the melt mixture of PP/CPA of nanosized silica and silicone fluid in the amount of 1.9 and 0.1 wt. $\%$, respectively, allowed realizing microfibrillar morphology in a four-component composition. In this case, the content of the polymer of dispersed phase in it is almost 1.5 times higher than in the nanofilled one. The use of two modifying additives has made it possible to give complex PP threads, along with improved durability and hygroscopicity, high abrasion resistance.

Increasing the concentration of fibre-forming polymer in the composition is one of the prerequisites for improving the economic performance and environmental safety of the production of thin-fibre materials by processing mixtures of polymers.

Developed software for mathematical planning and analysis of experiments in the study of four-component systems will accelerate the execution of research and obtain the results as close as possible to the optimum.

\section{REFERENCES}

1. S. Thomas, R. Mishra, and N. Kalarikka, Micro and Nano Fibrillar Composites ( $m f c s$ and $n f c s$ ) from Polymer Blends (Cambridge, UK: Woodhead Publishing: 2017).

2. L. A. Utraki and C. A. Wilkie, Polymer Blends Handbook (London-New YorkHeidelberg-Dordrecht: Springer: 2014). doi.org/10.1007/978-94-007-6064-6.

3. Vu Anh Doan and Masayuki Yamaguchi, Recent Res. Devel. Mat.Sci., 10: 59 (2013).

4. N. H. A. Tran, H. Brünig, R. Boldt et al., Polymer, 55, No. 24: 6354 (2014). doi.org/10/1016/j.polymer.2014.10.002

5. N. M. Rezanova, Yu. O. Budash, and V. P. Plavan, Innovatsiyni Tekhnologii Khimichnykh Volokon [Innovative Technologies of Chemical Fibers] (Kyiv: Kyiv National Univ. of Techn. and Design: 2017) (in Ukrainian).

6. M. V. Tsebrenko, V. G. Rezanova, and I. O. Tsebrenko, J. of Mater. Sci. and Eng., 4, No. 6: 36 (2010).

7. N. M. Rezanova, I. A. Melnyk, M. V. Tsebrenko, and A. V. Korshun, Khim. Volokna, 1: 23 (2014) (in Ukrainian).

8. K. Jin, S. Eyer, W. Dean, D. Kitto, F. S. Bates, and C. J. Ellison, Industrial and Eng. Chem. Res., 59, No. 12: 5238 (2019). https://doi.org/10.1021/acs.iecr.9b04887

9. C. J. Ellison, A. Phatak, D. W. Giles, and F. S. Bates, Polymer, 48, No. 11: 3306 (2007). doi.org/10.1016/j.polymer.2007.04.005

10. N. H. A. Tran, H. Brünig, M. A. Landwehr, R. Vogel, and G. Heinrich, J. Appl. Polym.Sci., 133: 442 (2016). doi.org/10/1002/app.44259

11. W. Li, J. Karger-Koksis, and A. K. Schlarb, Macromol. Mater. Eng., 294: 582 (2009). doi.org/10.1002/mame.200900123

12. Z. Pan, M. Zhu, Y. Chen, L. Chen, W. Wu, Ch. Yu, Z. Xu, and L. Cheng, Fibers and Polym., 3: 494 (2010). doi.org/10.1007/s12221-010-0494-x

13. V. A. Beloshenko, V. P. Plavan, N. M. Rezanova, B. M. Savchenko, and 
I. Vozniak, The Inter. J. of Advan. Manufact. Techn., 101: 2681 (2019). doi:10.1007/s00170-018-3152-x

14. V. G. Rezanova and M. V. Tsebrenko, Khim. Volokna, 2: 21 (2003) (in Ukrainian).

15. V. G. Rezanova and M. V. Tsebrenko, J. of Eng. Phys. and Thermophys., 81, No. 4: 766 (2009).

16. N. M. Rezanova, V. P. Plavan, L. S. Dzubenko, O. O. Sapianenko, P. P. Gorbyk, and A. V. Korshun, Nanosistemi, Nanomateriali, Nanotehnologii, 16, No. 1: 55 (2018) (in Ukrainian). https://doi.org/10.15407/nnn.16.01.055

17. N. M. Rezanova, B. M. Savchenko, V. P. Plavan, V. Yu. Bulakh, and

N. V. Sova, Nanosistemi, Nanomateriali, Nanotehnologii, 15, No. 3: 559 (2017) (in Ukrainian); https://doi.org/10.15407/nnn.15.03.0559

18. N. M. Rezanova, V. P. Plavan, V. G. Rezanova, and V. M. Bohatyryov, Vlákna a Textil, 23, No. 4: 3 (2016).

19. N. M. Rezanova, V. G. Rezanova, V. P. Plavan, and O. O. Viltsaniuk, Vlákna a Textil, 24, No. 2: 37 (2017).

20. N. M. Rezanova, V. G. Rezanova, V. P. Plavan, and O. O. Viltsaniuk, Functional Mat., 26, No. 2: 389 (2019); doi.org/10.15407/fm26.02.389

21. I. G. Zedginidze, Planirovanie Ehksperimenta dlya Issledovaniya Mnogokomponentnykh Sistem [Planning an Experiment to Study Multicomponent Systems] (Moscow: Nauka: 1976) (in Russian).

22. S. L. Akhnazarova and V. V. Kafarov, Metody Optimizatsii Ehksperimenta v Khimicheskoy Tekhnologii [Methods of Experiment Optimization in Chemical Technology] (Moscow: High School: 1985) (in Russian).

23. N. Kultin, Osnovy Programmirovaniya v Delphi 7 [Programming Basics in Delphi 7] (St. Petersburg: BHV-Peterburg: 2012) (in Russian).

24. N. Kultin, Delphiv Primerakh i Zadachakh (3 Izd.) [Delphi in Examples and Problems ( $3^{\text {rd }}$ Edition)] (St. Petersburg: BHV-Peterburg: 2012) (in Russian).

25. M. Flenov, Bibliya Programmista (Delphi) [Bible of programmer (Delphi)] (St. Petersburg: BHV-Peterburg: 2011) (in Russian).

26. N. Dreiper and G. Smith, Prikladnoy Regressionnyy Analiz [Applied Regression Analysis] (Moscow: Villiams: 2016) (in Russian).

27. V. Yu. Shcherban, S. M. Krasnitskiy, and V. G. Rezanova, Matematychni Modeli v SAPR. Obrani Rozdily ta Pryklady Zastosuvannya [Mathematical Models in SAPR. Selected Sections and Examples of Application] (Kyiv: Kyiv National Univ. of Techn. and Design: 2011) (in Ukrainian). 